\title{
Distributional Effects of Human Capital in Advanced Economies: Dynamics of Economic Globalization
}

\section{Onur Ozdemir ${ }^{\mathrm{a}}$}

Abstract: This study investigates the human capital-income inequality nexus for 19 advanced economies. The whole sample covers the period between 1990 and 2017. The econometric analysis considers two fundamental panel data methods, namely the fixedeffects and two-step system GMM, to test whether the correlation between human capital development and income inequality is negative or not. The empirical findings of these two particular panel data methods reveal that while the initial stages of accumulating a higher degree of human capital through increasing the average years of schooling and returns to education reduce the level of income inequality, the later stages show that this negative relationship turns into positive by way of widening the unequal distribution of national income. In addition, the economic globalization appears to be positively correlated with income inequality, meaning that globalized economic relations widen the scale of inequality where the statistical significance of human capital-income inequality nexus still prevails. All these estimation results show that they are contradicted with the mainstream findings, each of which puts forward that higher level of human capital reduces the level of income inequality.
Keywords: Human Capital, Income Inequality, Economic Globalization, Education, Income Distribution

JEL: D63, 124, I26

$\begin{array}{ll}\text { Received } & : 02 \text { April } 2020 \\ \text { Revised } & :-- \\ \text { Accepted } & : 27 \text { May } 2020 \\ \text { Type } & \text { : Research }\end{array}$

\section{Introduction}

Increasing level of human capital has been considered as one of the core factors affecting the level of income inequality. Thus, the existing literature consists of voluminous studies on the relationship between human capital and income inequality. It is widely agreed upon the fact that the accumulation of human capital is positively correlated and statistically significant with the income level of the individuals, covering both national and international units. However, the recent studies have shown that this traditional wisdom could be changed depending on several reasons such as the skill premia, earning opportunities, social background, and political ingredients. In that sense, the link between human capital and income inequality may not be that straightforward. Given that there may be nonlinearities in returns to education and schooling, even an equalizing increase in human capital accumulation may lead to an uneven variance in the distribution of aggregate incomes (Battistón et al., 2014). This phenomenon is called as "the paradox of progress", which is pioneered by Bourguignon et al. (2005), to reveal the case that the educational expansion is linked with a surge in income inequality.

On the other side, rising income inequality as a major issue in the economic discipline has attracted attention across many countries, including both developed and developing, over recent decades (OECD, 2008; Atkinson et al., 2011; Piketty, 2014; Dabla-Norris et al., 2015; Milanovic, 2018). In particular, the formal

a Asst. Prof., PhD., Istanbul Gelisim University, Faculty of Economics, Administrative and Social Sciences, Department of International Trade (English), Istanbul, Turkiye, onozdemir@gelisim.edu.tr (ORCID ID: 0000-0002-3804-0062) 
analyses on the case of rising income inequality stimulated by its correlation with the economic growth (Kuznets, 1955; Kaldor, 1957). Related to the relationship between economic growth and inequality, it has been produced many aspects of the ongoing debate. One critical issue pertains to the question of reasons and dynamics: What are the major factors lead to a rising income inequality? Does income inequality affect the growth rate or vice versa? Is there any significant cause of income inequality on social strata? These are some of the basic questions, which are still waiting to be answered in the economics literature and other social disciplines as well.

Considering this background, the major aim of this paper is to focus on one of the specific factors, namely the human capital accumulation, as a determinant of the deterioration of income distribution across the advanced countries over the period 1980-2017. The starting point for the education-inequality nexus can be found in studies proposed by Mincer (1958) and Becker (1962). The initial findings about that nexus have shown that the positive effect of education on income inequality is straightforward, which means that a higher level of education alleviates the unequal distribution of incomes among people. Williamson (1991), for example, supports the empirical evidence for the case that a higher degree of accumulation in human capital by way of a developed education system allows for a decrease in wealth inequality along with higher economic growth rates. Moreover, the returns to education are greater for higher education compared to the primary and secondary schooling (Montenegro and Patrinos, 2014). On the other way, Checchi (2000), Rodríguez-Pose and Tselios (2009), and Battistón et al. (2014) point to the effects of expansion in education level on income polarization. They mainly argue that the nation's educational system should be developed in specific fields to lead to a smaller spread of income polarization.

Accompanying this, some evidence on the link between human capital accumulation and rising income inequality has been identified in the form of higher skill premia (Mitchell, 2005). This case is based on an increase in returns to skilled versus unskilled labor along with changing the composition of the production system. For instance, some of the studies, thus, argued that human capital has replaced the status of physical capital as the leading component of economic growth (Galor \& Moav, 2004; Ehrlich \& Kim, 2007). In particular, the debate on skill-bias has substantially moved to investigate the differential effects of demand in labor (Acemoglu \& Autor, 2010). For instance, OECD (2014) documents that low education is closely associated with lower employment rates and thereby lower wages. Although a bulk of studies focus on the composition of labor demand and the educational expansion, an increase in human capital has led to a larger supply of skilled and highly qualified workforce, which has stimulated to investigate the effects of educational inequality on wage inequality. According to Goldin and Katz (2010), a greater share of rising wage inequality can be accompanied by an increasing educational wage differential.

Related to the wage differential led by educational expansion, some major studies (Becker \& Tomes, 1979; Galor \& Zeira, 1993; Viaene \& Zilcha, 2003, Peracchi, 2006; Rodríguez-Pose \& Tselios, 2009) reveal that disparities in educational attainment can also be seen as one crucial factor of increasing level of income inequality. While Saint-Paul and Verdier (1993) argue that distribution of income is linked to a change in political equilibrium in the way that public education, Durlauf (1996) indicates to the persistence of income inequality by way of analyzing the human capital formation. Park (1996) and De Gregorio and Lee (2002) find that a lower rate of disparities in educational attainment has an equalizing effect on income distribution. Conversely, Ram (1984) argues that this equalizing effect of educational attainment is mild when income distribution is considered. However, Checchi (2001) remarks that if the educational expansion is achieved in the social sphere, the rising income inequality will be held down. This point also leads some studies to examine the linear and nonlinear relationship between education inequality and years of schooling (Ram, 1990; Thomas et al., 2002) where the inverted U-shaped relations is apparent, indicating that there is a positive correlation between educational inequality and average years of schooling at the initial periods but it turns to be a negative at the latter phases of development. Galor (2012) also puts forward an argument that educational investments may be restrained when households are constrained to reach liquid units if there is an expansion in earnings inequality.

Although the evidence on the relationship between education and income inequality is positively supported by a bulk of studies, the others assert that a negative relationship is plausible. Knight and Sabot 
(1983) argue that the expansionary effect of education on income distribution is not clear since it includes two offsetting mechanisms to reduce inequality level of income. First, there is a "composition effect", which implies that a surge in income inequality becomes a fact when the proportion of more educated workers increases together with the educational expansion. Second, there is a "wage compression effect", which refers to the case that wage inequality becomes lower when the supply of labor is higher than the demand for labor along with the educational expansion. In other words, an increase in the supply of labor leads to push wages of highly educated workers down in the long run. Besides, Bourguignon et al. (2005) state that there may be a higher degree of polarization in incomes when there is a considerable level of development in the education system. Autor (2014) suggests that higher skill premia and educational expansion emerged in many developed economies in recent years, tend to contribute a surge in earnings inequality. CamposVazquez et al. (2014) and Lustig et al. (2016) point on "paradox of progress" produced by Bourguignon et al. (2005) to show that the negative impact of a higher level of education on income inequality is plausible when there is non-linearity in returns to schooling/education. Jaumotte et al. (2013) indicate that income inequality has a positive and significant link with an increase in the share of population with secondary and tertiary education, holding the average education constant. Psacharopoulos and Patrinos (2004) suggest the returns on education decrease with the level of schooling.

However, the last group of studies find neither positive nor negative effect of education on income inequality. For instance, Földvári and van Leeuwen (2011) identify that the equalizing effect of schooling inequality on income inequality is insignificant. In a seminal paper, Spence (1973) also finds a non-robust relationship between education and income distribution. Galor and Tsiddon (1997) and Wolf (2004), for instance, suggest that there is no direct link between education and income inequality. Rather, the authors argue that genetic and cognitive abilities are the leading factors for the case of a surge in income equality, compared to the level of education. In other words, the reward mechanism based on income is structured upon the abilities of employees.

Although the empirical and theoretical findings on the relationship between education and income inequality are mixed and controversial, there are also other channels of influences, examined in a broader sense, which lead many studies to focus on those research fields. On the one hand, less attention has been devoted to the characteristics of educational systems and income inequality. According to Checchi and van de Werfhorst (2014), two different forms of inequality have been addressed, which are inequality as dispersion and inequality of educational opportunity. Therefore, the other characteristics of educational systems-inequality nexus can provide different pieces of evidence, ignoring these two forms of inequality. For instance, Pfeffer (2008) and Bol and van de Werfhorst (2013) find that there is no correlation between the size of the private schooling sector and the level of inequality. Wossmann (2005) also remarks that social accountability is negatively correlated to the inequalities in student achievement by parental education. Rumberger (2010) implies that social background contributes to college completion for which case that the students from high socioeconomic status have more chances to finish college than the other students who are not socially advantageous as a class. Hanushek and Wossmann (2011) point to the case that institutional effects have a much stronger impact on student learning than the features of the country.

On the other hand, the changes in the intergenerational framework can influence income inequality concerning the level of education. For example, Katz and Murphy (1992) indicate that the changes in the relative earnings of college graduates and the changes in the wage structure for the U.S. economy over the 1963-1987 period are strongly correlated with each other. This shows that the demand for skilled labor exceeds the supply of college graduates and thus the wages for the former part begin to increase in the long run by way of altering the within income distribution among the workers. Gregg et al. (2019) focus on social status and validate the intergenerational framework by making the following argument that social strata and family background can have potential effects on educational patterns, and thereby, the personal efforts can be treated as less important than the former one. Andersen (2019) also evaluates how intergenerational framework relates to the educational attainment. The author's argument follows the proposition in which a parent's education has a strong impact on the level of education of their children. In other words, welleducated parents are more prone to provide a college education to their children. Therefore, this leads to 
relatively higher wages for the children who are relatively well-educated and attained in the educational system.

Despite the large differences in understanding of the relationship between education and income inequality, there is a considerable number of new phenomena emerging as a new factor in socioeconomic framework that leads to change the effects of education on income distribution. This study adds to the existing literature by considering both the labor market indicators and economic globalization data consisting of 19 advanced economies $^{1}$ from 1990 to 2017, which contradicts with the previous papers validating the negative and significant correlation among education and income inequality, includes several proxy variables. Primarily, the human capital, which is used to measure the level of education, is comprised of both the years of schooling and the returns to education. Therefore, it is assumed that the human capital is attained through education and the acquisition of skills. In addition to human capital index, the empirical analysis considers economic globalization index, unemployment rate, Gross Domestic Product (GDP) per capita, inflation rate, 15-65 years of population ratio, Human Development Index (HDI), and education index. In particular, some of the labor market indicators such as unemployment rate and population ratio have unique features to affect the level of inequality through the change in the bargaining power of labor and the change within the class dynamics. For instance, considering the division between skilled and unskilled workers, the higher and persistent unemployment rate increases the wage inequality among different segments of society and thus widens the income polarization through reducing the bargaining power of labor in favor of capital. Similarly, it is widely recognized that a high inflation rate, especially those who own lower wage levels, have ample impact on the standard of livings along with eroding purchasing power. The evidence on economic globalization, covering both trade and financial openness, is mixed but for the most part indicates a negative impact of the globalized economy on income distribution. The inclusion of GDP per capita in logarithmic form is substantially crucial since it is proxied for measuring the level of economic development. Furthermore, the study considers the human development index as a variable to measure the effects of four principal areas of interest: mean years of schooling, life expectancy at birth, expected years of schooling, and income per capita. However, some models will exclude HDI to get rid of the multicollinearity problem. Finally, the paper includes an education index as an alternative measurement for the human capital index, which is calculated using means years of schooling and expected years of schooling. This is used as a proxy variable since different from the human capital index, it neglects the returns to education. By controlling for various control variables that may have a significant effect on income inequality, the study investigates more precisely the distributional effects of human capital, as such, the empirical findings will conclude that the educationinequality nexus has contradictory outputs compared to the traditional wisdom.

The remainder of the paper is structured as follows. Section 2 provides some stylized facts about the income inequality, human capital, and economic globalization. Section 3 sets out the explanation of the data which is used in the empirical part. Section 4 devotes to represent the empirical findings based on different methods. Section 5 presents the concluding remarks.

\section{Stylized Facts}

Figure 1 depicts the average GINI and average human capital over the 1990-2017 period for the 19 advanced economies, which are obtained from Solt (2019) and Penn World Tables version 9.1, respectively. The figure shows that a higher degree of human capital is substantially correlated to smaller income inequality levels, represented by the GINI index. However, countries with low degree of human capital such as Italy, Singapore, and Spain represent a somewhat higher level of income inequality. However, this is not the only criterion since the United States and the United Kingdom have the highest levels of years of schooling and returns to education along with the highest levels of inequality. Therefore, it has not a strict rule that the inequality widens in countries where the degree of human capital is below the certain level such as 3 . Moreover, notice that countries with the highest GDP per capita (e.g., Australia, Canada, the United Kingdom, and the United States) report high-income inequality whereas countries with the lowest GDP per capita (e.g., Austria, Belgium, and Finland) exhibit a high degree of human capital and low levels of inequality. 
Figure 1. Income Inequality and Human Capital, Average Years from 1990 to 2017

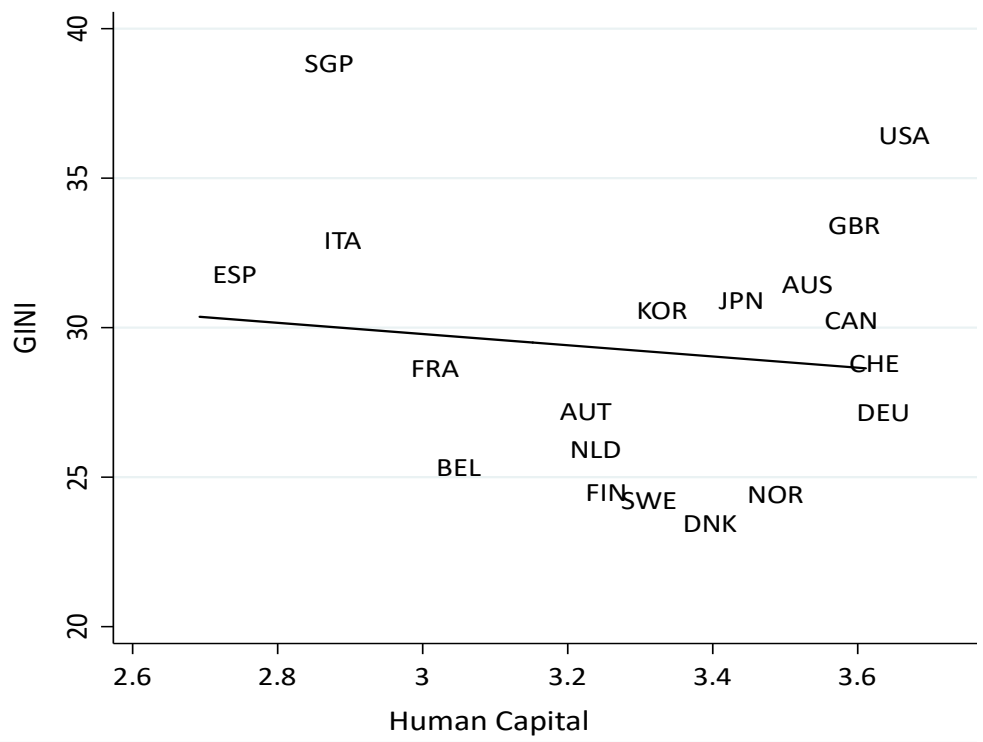

Source: Solt (2019); Penn World Tables 9.1; Author's Calculation

Figure 2 shows the average GINI and average economic globalization over the 1990-2017 period for the 19 advanced economies, which are obtained from Solt (2019) and KOF Globalisation Index, respectively. The graphical representation implies that the levels of income inequality have a downward trend along with an increasing degree of economic globalization. However, the direction of correlation is not straightforward. For example, Singapore reports high-income inequality where the degree of economic globalization is much higher compared to other countries. This leads us to examine other economic and social factors to understand why the GINI index is much higher than the other countries along with the consideration of changing in economic globalization index. This case also holds for the other countries which of those have the same trend. In that sense, the econometric analysis, consisting of different types of control variables, will provide exact evidence.

Figure 2. Income Inequality and Economic Globalization, Average Years from 1990 to 2017

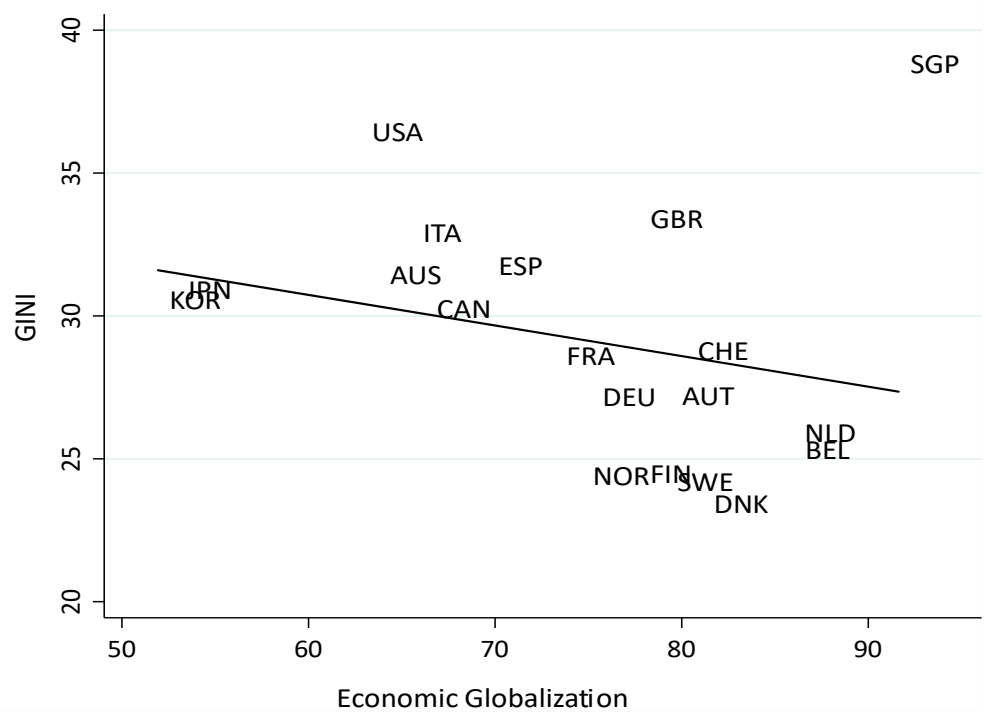

Source: Solt (2019); KOF Globalization Index; Author's Calculation 
Figure 3. Income Inequality and Human Capital, Average Years from 1990 to 2006

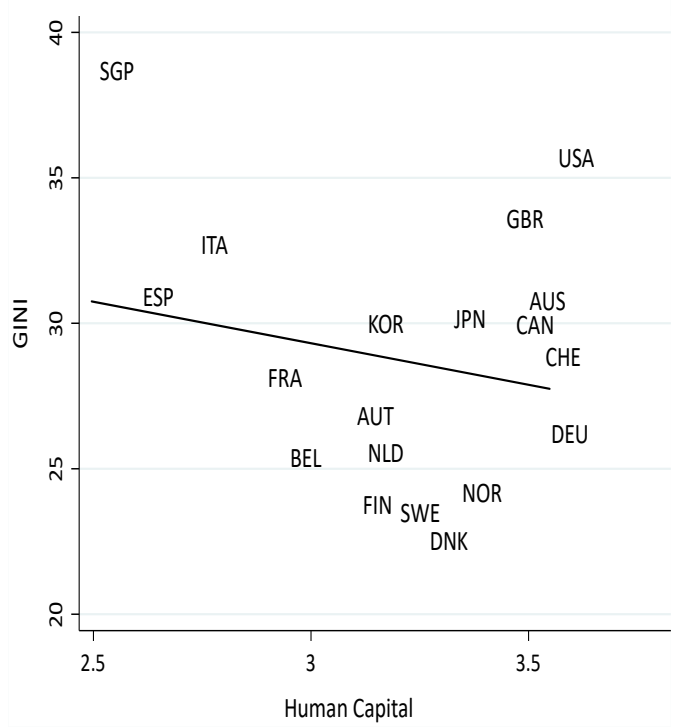

Figure 4. Income Inequality and Human Capital, Average Years from 2007 to 2017

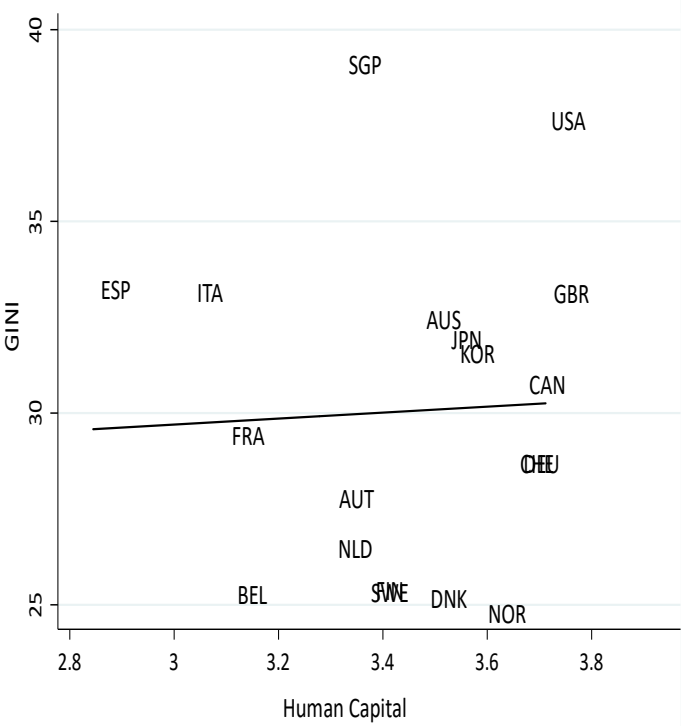

Source: Solt (2019); Penn World Tables 9.1; Author's Calculation

Figure 5. Income Inequality and Economic Globalization, Average Years from 1990 to 2006

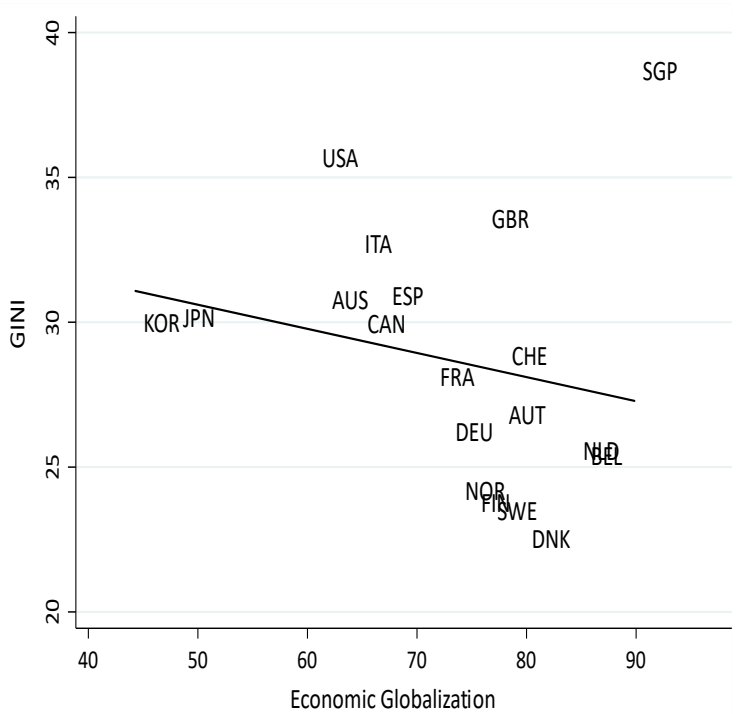

Figure 6. Income Inequality and Economic Globalization, Average Years from 2007 to 2017

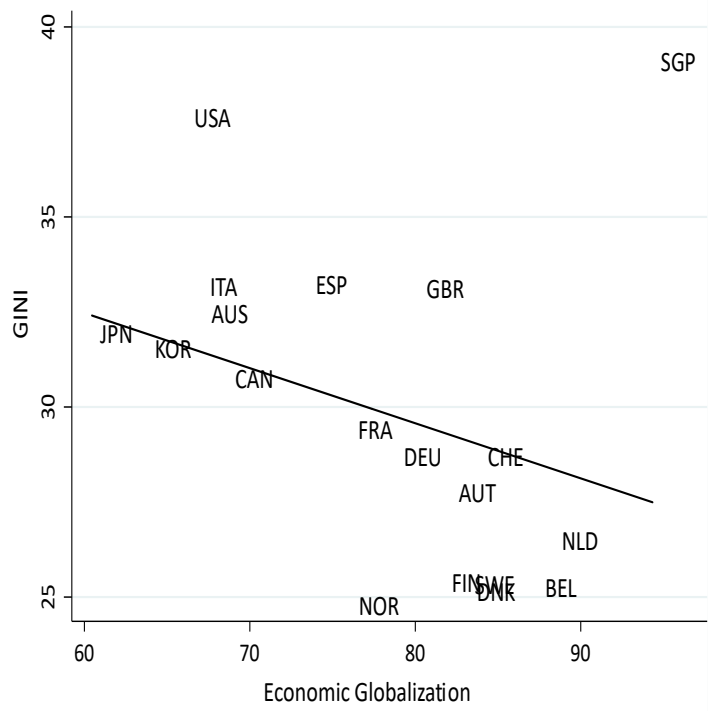

Source: Solt (2019); KOF Globalization Index; Author's Calculation

Figures 3 and 4 depict the average changes between income inequality and human capital for two periods. The distinction is determined in terms of the starting date of the global financial crisis, which has been emerged in 2007 and still goes on across the nations. The major reason to divide the period into two pieces depends on the fact that the inequality-education nexus may be changed across nations and throughout time. ${ }^{2}$ In particular, two graphs show that the sample 19 advanced economies experienced an overall increase in human capital; while the degree of human capital index below three in the period between 1990 and 2006 included Belgium, France, Italy, Singapore, and Spain the period between 2007 and 2017 showed that there was only one country - namely Spain - below the number of three. However, the same negative trend cannot be put forward for the level of income inequality. The comparison between two figures indicates that only one country - namely Norway - is below 25 in terms of the period between 2007 and 
2017. However, Figure 3 shows that the number of countries below 25 in the period between 1990 to 2006 was much higher, including Denmark, Finland, Norway, and Sweden. Overall, as it is clear that the negative relationship among two indicators do not perceive throughout time. In other words, although the degree of human capital increases across countries, it does not follow the decreasing level of income inequality.

Also, Figures 5 and 6 seek to understand the averages for a given period distinction based on the relationship between income inequality and economic globalization. The major reason to add economic globalization indicator into the graphical analysis depends on the fact the it shows the weighted average of both trade and financial openness, which are highly correlated to the changes in labor market indicators in line with the changes in the bargaining power of labor throughout time. As it is clear from the figures that the fitted values are downward sloping, indicating that the negative relationship between inequality and openness is straightforward for two periods in time. While this is plausible to note by way of looking at trends in two indicators, Figure 6 shows that the degree of economic globalization has further increased after the global crisis of 2007 and 2008. Moreover, the comparison between two periods reveals that an increasing level of income inequality follows an increasing scale of economic globalization across selected 19 advanced economies.

All in all, while both human capital and economic globalization are negatively correlated with the GINI coefficient according to the above-mentioned figures in both periods, the study treats these findings in caution since it argues that the control variables can differ the overall results of stylized facts. Considering this case, the following part summarizes the data for the empirical analysis that the study includes as control variables to examine the exact relationship between human capital and income inequality.

\section{Data and Empirical Methodology}

\subsection{Data}

The empirical analysis consists of several control variables in addition to the benchmark variables such as the GINI coefficient, human capital, and economic globalization indices. For the dependent variable, the study uses the GINI index of disposable income inequality - namely the GINI Net - as a measure of personal income distribution, which is obtained from the Standardized World Income Inequality Database (SWIID) produced by Solt (2019). The use of GINI Net variable depends on its benefit that the taxes and transfers are adjusted from the data. Also, SWIID provides one of the most comprehensive and long run data for GINI indices of disposable and market inequality for 196 countries, covering both developed, developing, and least developed economies.

As a measure of human capital, the study uses the combined data for both average years of schooling obtained in Barro and Lee (2013) and rate of return to education based on Mincer equation estimates around the world proposed by Psacharopoulos (1994) from the Penn World Tables version 9.1 provided by Feenstra et al. (2015). The major advantage of this combined human capital data is that the rate of returns to education is also calculated together with the average years of schooling. By using this variable, the comprehensive effects of human capital accumulation on income inequality can thus be measured for the long run period.

Data on bargaining power measures come from World Development Indicators (WDI) database provided by World Bank. First, the unemployment rate is measured as a percentage of total labor force. Second, the population ratio is comprised of 15-65 years of working age people.

Economic globalization is a weighted average of both trade and financial openness calculated as index and obtained from the KOF Globalization Indices. This database divides the globalization indicators into three sub-categories. While one of them is economic globalization index, the others are social and political indices. They all include different types of variables according to their fields.

In the empirical analysis, the study also includes macroeconomic and structural variables such as GDP per capita and inflation rate. All of these variables will be obtained from the WDI database of World Bank. 
Finally, the study uses some proxies for GDP per capita and human capital index. On the one hand, the human development index is proxied as an alternative variable instead of GDP per capita. On the other hand, the education index is used as an alternative variable to check whether the given correlation between the human capital index and the GINI coefficient is still prevailing. Both two variables are obtained from the United Nations Development Programme (UNDP) database.

Table 1 summarizes the descriptive statistics for both regressand and regressors used in the empirical analysis. ${ }^{3}$ For example, the median value of income inequality, representing by the GINI index, is 28.9 , which means that $50 \%$ of the sample countries have experienced a GINI coefficient lower than 28.9 , and the rest of the $50 \%$ a higher coefficient over the 1990-2017 period. The maximum level of income inequality, the GINI coefficient of 39.5, corresponds to Singapore for the period between 2007 and 2010 . This is the maximum level that none of the countries touch that level of income inequality. The minimum level of income inequality, the GINI coefficient of 21, corresponds to Finland in 1990 and 1991 . Notice that all the variables are structured as balanced data where the number of observations is 532 .

Table 1. Descriptive Statistics

\begin{tabular}{lcccccc}
\hline \hline Data & No. of Obs & Mean & Median & Min. & Max. & Std. Dev. \\
\hline GINI & 532 & 29.3 & 28.9 & 21 & 39.5 & 4.31 \\
HumCap & 532 & 3.26 & 3.31 & 2.05 & 3.97 & 0.32 \\
Econ_Glob & 532 & 73.4 & 75.2 & 33.1 & 95.3 & 11.8 \\
Unemp & 532 & 6.99 & 6.17 & 1.78 & 26.1 & 3.78 \\
Log(GDP) & 532 & 4.61 & 4.62 & 3.93 & 4.96 & 0.15 \\
Inflation & 532 & 2.09 & 1.98 & -1.35 & 10.4 & 1.59 \\
Population & 532 & 67.2 & 66.8 & 60.1 & 78.7 & 2.88 \\
HDI & 532 & 0.87 & 0.88 & 0.72 & 0.95 & 0.04 \\
Education & 532 & 0.81 & 0.82 & 0.49 & 0.95 & 0.08 \\
\hline \hline
\end{tabular}

\subsection{Empirical Methodology}

The empirical analysis and the methodology of this paper depend on two hypotheses, which of those can be ranged as follows:

H1. There is a negative correlation between human capital development and income inequality in the initial period but it turns into positive for the future period.

H2. Economic globalization decreases the bargaining power of labor and thereby increases the overall level of income inequality.

Based on two hypotheses, the paper aims to test the relationship between human capital accumulation and income inequality over the 1990-2017 period for 19 advanced economies selected in terms of their level of economic development. In particular, the testing procedure of this relationship depends on two different types of econometric methods. On the one hand, it will be used fixed-effects panel data models to account for unit-fixed effects. On the other hand, the empirical analysis will also be benefited from the system-GMM procedure to account for the endogeneity problem, which is not adjusted in the fixed-effects method.

First, in the case of fixed-effects panel data models, the above-mentioned benchmark relationship between the two variables is estimated in Eq. (1) as follows:

$$
\operatorname{GINI}_{i t}=\beta_{i t}+\alpha \operatorname{HumCap}_{i t-k}+\lambda \mathrm{HumCap}_{i t-k}^{2}+\gamma X_{i t-k}^{\prime}+\theta_{t}+\mu_{i}+u_{i t}
$$

where $G_{I N I}$ it is the income inequality variable, representing the GINI coefficient, of country $i$ in period $t, \beta_{i t}$ denotes the constant term, $\mathrm{HumCap}_{i t-k}$ refers the human capital accumulation, $\mathrm{HumCap}{ }_{i t-k}^{2}$ denotes the 
square term of human capital accumulation to assess whether there is a change over time, $X_{i t-k}^{\prime}$ denotes a vector of control variables, $\theta_{t}$ captures the unobserved time effects, and $\mu_{i}$ shows the unobserved unit-fixed heterogeneity. $u_{i t}$ is independent and identically distributed (i.i.d.) error term. While the system-GMM model allows for adjusting the heterogeneity problem, the same issue is also considered in fixed-effects panel data models. Therefore, to remove the heterogeneity problem from the estimated models, the standard errors are clustered at the country level. Also, the other diagnostic problems such as cross-sectional dependence are considered in the fixed-effects panel data models.

Second, in consideration of the endogeneity problem, the study also utilizes a two-step system-GMM procedure. In that sense, Eq. (2) represents the system-GMM estimator developed by Arellano and Bover (1995) and Blundell and Bond (1998) to adjust from the correlation problem among two parameters, namely $\mu_{i}$ and $G I N I_{i t-k}$. Different from the Eq. (1), the first-difference transformation is used in Eq. (2) to get rid of potential unit-fixed effects. The following equation represents the regression model of so-called issue:

$$
\Delta G I N I_{i t}=\alpha \Delta G I N I_{i t-k}+\lambda \Delta H_{u m C a p} \operatorname{ct}_{-k}+v \Delta \operatorname{HumCap}_{i t-k}^{2} \gamma \Delta X_{i t-k}^{\prime}+\Delta \theta_{t}+\Delta u_{i t}
$$

where $\Delta$ denotes the first-difference transformation estimator representing in a simple equation as $\Delta G I N I_{i t-k}=G I N I_{i t}-G_{I N I_{i t-m}}$. Besides, the orthogonality conditions should be provided in system-GMM models where $E\left(G I N I_{i t-k} \Delta u_{i t}\right)=0 . G I N I_{i t-k}$ denotes the optimal lag length of the GINI coefficient to measure the level of income inequality. By following the argument of Heid et al. (2012), the second and further lags of $G I N I_{i t}$ are integrated into the models as instruments for the residuals. Also, one of the major issues of Ordinary Least Squares (OLS) estimates is that the estimation outputs can be biased for both $\alpha$ and $\lambda$ due to two reasons (Che et al., 2013). First, $G I_{N I-k}$ is a function of i.i.d. error term. Second, $\operatorname{Cov}\left(\Delta G I N I_{i t-k}, \Delta u_{i t}\right) \neq 0$. Last but not least, there must be no second-order serial correlation in $\Delta u_{i t}$ to provide consistent estimation results. To reach that conclusion, the empirical method considers the use of AR(2) test which is suggested by Arellano and Bond (1991) to test whether there is a second-order serial correlation of $\Delta u_{i t}$. Orthogonality conditions are also controlled by utilizing the J-test (i.e., the overidentification test) of Hansen (1982) to determine whether the excluded instruments provide valid orthogonality conditions.

All in all, the system-GMM estimator increases the asymptotic efficiency gains together with the moment conditions. Considering that case, Hansen (1982) also develops the difference J-test. However, the advantageous side of the system-GMM procedure resulting from the asymptotic efficiency gains can turn into negative since the orthogonality conditions of both J-tests, including level and difference, through the increase in the number of instruments over time. The positive relationship between the time dimension and the number of instruments is also labeled as size distortion in the empirical methodology (for more technical information, see Andersen and Sørensen, 1996; Bowsher, 2002; and Roodman, 2009). For instance, Roodman (2009) argues that the proliferation of the number of instruments induces two basic technical problems such as finite sample bias and misleading results of specification tests. Therefore, the major procedure to solve that further issue is to use a collapse option to reduce the possible finite sample bias and thereby to provide orthogonality conditions. The next section shows the empirical results based on the above-mentioned econometric procedures.

\section{Empirical Findings}

\subsection{Results of Fixed-Effects Panel Regression}

Table 2 shows the empirical results based on using a fixed-effects panel data method produced by Driscoll and Kraay (1998), which produces robust standard errors for panel regressions with cross-sectional dependence. In each model, the human capital-income inequality nexus is estimated through various control variables. First, Model (1) describes the partial relationship between the two variables. The benchmark correlation among these two variables implies that the level of income inequality increases along with a higher accumulation degree of human capital. However, as it is clear from the given regression that the 
correlation may not be straightforward for the long run process and throughout time. Model (2) shows that the economic globalization variable (i.e., Econ_Glob) has positively correlated with the income inequality, which validates the Hypothesis 2 presented in empirical methodology. In this sense, it should be point to the fact that the empirical process ignores the other determinants of globalization such as social and political to give more weight to assess the economic dynamics related to human capital accumulation. Therefore, the estimation results are based on the case that each model considers the equal significance of the variables in terms of the relationship between income inequality and human capital accumulation. This limited side of the globalization phenomenon is analyzed by way of considering economic variables, which are treated as proxy variables. They can be ranged as follows: (i) trade openness, (ii) financial openness, and (iii) foreign direct investment, covering both inflows and outflows.

Model (3) extends the benchmark relationship between the GINI coefficient and the human capital index by using the square term of human capital. The regression output presenting in Model (3) reveals the case that the initial periods of accumulation in human capital have negative impacts on income inequality but the correlation turns into positive over time. In other words, it means that ignoring the square term of human capital accumulation from the regression analysis provides a partial understanding of the overall effects of education on income inequality. Each model also includes the unit-specific effects to control the heterogeneity among different units. Moreover, to check whether the series are stationary, the study uses the IPS test produced by Im et al. (2003) since the series may follow a non-stationary trend in unit-root tests. This leads to empirical results to be more reliable and thus conducts effective assumptions.

Model (4) also includes the unemployment rate as a proxy variable to account for the bargaining power of workers. The coefficient of unemployment rate is positive and statistically significant in this model and the others. In other words, related to the existing literature, the empirical evidence supports the main arguments that the negative change in the bargaining structure of workers increases the level of income inequality in general. This also leads us to argue that the empirical findings in terms of the bargaining positions of workers do not support the contradictory assumptions produced by the mainstream wisdom, which remark that the factors of production earn incomes equal to their marginal productivities.

Model (5) adds the inflation ratio variable into the given regression to account for the effects of macroeconomic stability on income inequality. As one of the critical factors, the change in the inflation ratio over time may have a significant effect on purchasing power. Therefore, it should be empirically evaluated that a higher rate of inflation erodes the purchasing power of households and thus widens the gap between the rich and the poor. The empirical findings show that the correlation between inflation ratio and income inequality is insignificant though it is positive and thereby validates the above-mentioned proposition.

Related to the effects of macroeconomic ingredients on the income inequality-human capital accumulation nexus, Model (6) assess the impacts of the changes in the level of economic development and endowments proxied by the logarithmic term of GDP per capita (i.e., Log(GDPperCap)). Contrary to the inflation ratio, there is a positive and highly significant correlation between the level of economic development and endowments and income inequality. This also provides contradictory assumptions with the orthodox view since it is based on the argument that economic development and endowment is one of the ways to assess whether the resources are effectively used in the production process and are equally distributed in earnings. Model (7) also examines the theoretical significance of the Kuznets curve hypothesis of inequality by taking the square term of GDP per capita. The result of the regression shows that contrary to the inverted Kuznets curve, the U-shaped Kuznets curve hypothesis prevails as regards the relationship between GDP per capita and income inequality. It means that the initial stages of economic development reduce the income inequality by way of allocating the resources more equally, but further stages reveal that this negative link turns into positive since the revenues of production accumulate in hands of few economic units.

Furthermore, Models ( 8 ) and (9) adds an alternative measure of human capital accumulation, namely the human development index, which includes the economic and social components and thus refers to as composite index of life expectancy, education, and per capita income indicators. These models also embody 
the 15-65 years of population ratio into the regression estimations to cover the effects of population growth on income inequality through looking at the composition of the working-age population. First, the coefficient of human development index presents a positive and highly significant trend in both models. In other words, similar to the results obtained by regressing the logarithm of GDP per capita in the previous models, the persistence of a positive relationship between human development and income inequality is still prevailing. Second, the coefficient of 15-65 years of population ratio is negative and highly significant in Model (9). Therefore, it is clear to argue that a reduction in the working-age population decreases to get available resources and thus restricts to reach an equal distribution of income among different segments of the population.

Model (10) examines the effects of the square term of human development index (i.e. HDI^2) to empirically show whether the human capital Kuznets curve is still statistically significant and has the same trend as in the previous models. The estimation result in Model (10) reveals the fact that the expected signs of parameters obtained by regressing both $\mathrm{HDI}$ and $\mathrm{HDI}^{\wedge} 2$. This also means that while the initial periods of obtaining a higher level of human development reduces income inequality through providing a huge scale achievement of both education, life expectation, and per capita income to all citizens, the further periods show that these kinds of opportunities become available for less amount of people who have economically more favorable.

Table 2. Benchmark Results of Fixed-Effects Method

\begin{tabular}{|c|c|c|c|c|c|c|c|c|c|c|}
\hline & (1) & (2) & (3) & (4) & (5) & (6) & (7) & (8) & (9) & (10) \\
\hline HumCap & $\begin{array}{c}2.992^{* * *} \\
(0.459)\end{array}$ & $\begin{array}{l}0.971^{* *} \\
(0.464)\end{array}$ & $\begin{array}{l}-1.696 \\
(1.381)\end{array}$ & $\begin{array}{l}-2.393^{*} \\
(1.209)\end{array}$ & $\begin{array}{l}-2.400^{*} \\
(1.216)\end{array}$ & $\begin{array}{c}-3.26 * * * \\
(1.127)\end{array}$ & $\begin{array}{l}-1.848 \\
(1.098)\end{array}$ & & & \\
\hline HumCap^2 & & & $\begin{array}{l}0.433^{*} \\
(0.242)\end{array}$ & $\begin{array}{l}0.541^{* *} \\
(0.223)\end{array}$ & $\begin{array}{l}0.543 * * \\
(0.226)\end{array}$ & $\begin{array}{c}0.461^{* *} \\
(0.194)\end{array}$ & $\begin{array}{c}0.157 \\
(0.182)\end{array}$ & & & \\
\hline Econ_Glob & & $\begin{array}{c}0.098 * * * \\
(0.019)\end{array}$ & $\begin{array}{c}0.096^{* * *} \\
(0.019)\end{array}$ & $\begin{array}{c}0.100 * * * \\
(0.017)\end{array}$ & $\begin{array}{c}0.101^{* * *} \\
(0.018)\end{array}$ & $\begin{array}{c}0.064^{* * *} \\
(0.023)\end{array}$ & $\begin{array}{c}0.071^{* * *} \\
(0.020)\end{array}$ & $\begin{array}{c}0.064^{* *} \\
(0.024)\end{array}$ & $\begin{array}{c}0.061^{* *} \\
(0.023)\end{array}$ & $\begin{array}{c}0.071^{* * *} \\
(0.022)\end{array}$ \\
\hline Unemp & & & & $\begin{array}{l}0.055^{*} \\
(0.031)\end{array}$ & $\begin{array}{c}0.056^{* *} \\
(0.027)\end{array}$ & $\begin{array}{c}0.088^{* * *} \\
(0.027)\end{array}$ & $\begin{array}{c}0.107 * * * \\
(0.025)\end{array}$ & $\begin{array}{c}0.059^{* *} \\
(0.023)\end{array}$ & $\begin{array}{c}0.056^{* *} \\
(0.020)\end{array}$ & $\begin{array}{c}0.064^{* * * *} \\
(0.019)\end{array}$ \\
\hline Inflation & & & & & $\begin{array}{c}0.004 \\
(0.039)\end{array}$ & $\begin{array}{l}-0.004 \\
(0.035)\end{array}$ & $\begin{array}{l}-0.015 \\
(0.038)\end{array}$ & $\begin{array}{c}0.026 \\
(0.031)\end{array}$ & $\begin{array}{c}0.035 \\
(0.030)\end{array}$ & $\begin{array}{c}0.022 \\
(0.029)\end{array}$ \\
\hline $\log (G D P)$ & & & & & & $\begin{array}{c}6.535^{* * *} \\
(1.545)\end{array}$ & $\begin{array}{c}-63.564 * * * \\
(10.927)\end{array}$ & & & \\
\hline $\log (G D P)^{\wedge} 2$ & & & & & & & $\begin{array}{c}7.851^{* * *} \\
(1.160)\end{array}$ & & & \\
\hline HDI & & & & & & & & $\begin{array}{c}10.810^{* * *} \\
(2.760)\end{array}$ & $\begin{array}{c}10.539 * * * \\
(2.544)\end{array}$ & $\begin{array}{c}-83.43^{* * *} \\
(10.959)\end{array}$ \\
\hline$H D I^{\wedge} 2$ & & & & & & & & & & $\begin{array}{c}54.337 * * * \\
(6.347)\end{array}$ \\
\hline Population & & & & & & & & & $\begin{array}{c}-0.151^{* * *} \\
(0.021)\end{array}$ & $\begin{array}{c}-0.116^{* * *} \\
(0.028)\end{array}$ \\
\hline Constant & $\begin{array}{c}19.549 * * * \\
(1.569)\end{array}$ & $\begin{array}{c}18.927^{* * *} \\
(0.450)\end{array}$ & $\begin{array}{c}23.098^{* * *} \\
(2.419)\end{array}$ & $\begin{array}{c}23.559 * * * \\
(2.122)\end{array}$ & $\begin{array}{c}23.503^{* * *} \\
(2.059)\end{array}$ & $\begin{array}{l}-0.486 \\
(5.457)\end{array}$ & $\begin{array}{c}153.654^{* * *} \\
(24.150)\end{array}$ & $\begin{array}{c}14.683^{* * *} \\
(0.791)\end{array}$ & $\begin{array}{c}25.262^{* * *} \\
(1.516)\end{array}$ & $\begin{array}{c}62.758^{* * *} \\
(3.600)\end{array}$ \\
\hline R-squared & 0.265 & 0.427 & 0.428 & 0.440 & 0.441 & 0.465 & 0.506 & 0.479 & 0.511 & 0.525 \\
\hline No. of obs. & 532 & 532 & 532 & 532 & 532 & 532 & 532 & 532 & 532 & 532 \\
\hline No. of countries & 19 & 19 & 19 & 19 & 19 & 19 & 19 & 19 & 19 & 19 \\
\hline
\end{tabular}

Notes: * significant at the 0.10 level, $* *$ significant at the 0.05 level, $* * *$ significant at the 0.01 level. Robust standard errors are presented in parentheses.

Table 3 represents the estimation results of the sensitivity analysis made using the education index instead of the human capital index. The major reason to approach the sensitivity analysis is to show that a much narrower scale of education variable is still significant in the empirical context based on the relationship between income inequality and educational background. The results of alternative specifications for the fixed-effects method in Table 3 refers that the coefficient of education index is positive and almost statistically significant. In other words, similar to the previous empirical validity between income inequalityhuman capital nexus presented in Table 2, the same empirical outputs are also held for the case of using education index (i.e., Education) as an alternative variable to check the sensitivity of changes in income inequality. Also, the square term of education index (i.e., Education^ 2 ) is regressed together with the other control variables to check whether the same methodological background provides the similar results done for the square term of the human capital index. In that vein, the coefficients of both the education index and its square term follows the same empirical outputs that was previously obtained in Table 2 . Therefore, it is clear to argue that the initial periods of having more education reduces the income inequality but it becomes positive in the further periods. 
Distributional Effects of Human Capital in Advanced Economies: Dynamics of Economic Globalization

Table 3. Sensitivity Analysis - Fixed-Effects Method

\begin{tabular}{|c|c|c|c|c|c|c|c|}
\hline & (1) & $(2)$ & (3) & $(4)$ & $(5)$ & (6) & (7) \\
\hline Education & $\begin{array}{c}10.055^{* * *} \\
(0.199)\end{array}$ & $\begin{array}{l}5.146^{* *} \\
(1.870)\end{array}$ & $\begin{array}{c}-31.447^{* * *} \\
(6.102)\end{array}$ & $\begin{array}{c}-35.804 * * * \\
(6.796)\end{array}$ & $\begin{array}{c}-35.673^{* * *} \\
(6.821)\end{array}$ & $\begin{array}{c}-39.036 * * * \\
(6.437)\end{array}$ & $\begin{array}{c}-36.039^{* * *} \\
(7.179)\end{array}$ \\
\hline Education^2 & & & $\begin{array}{c}23.729 * * * \\
(4.389)\end{array}$ & $\begin{array}{c}26.419 * * * \\
(4.849)\end{array}$ & $\begin{array}{c}26.428^{* * *} \\
(4.796)\end{array}$ & $\begin{array}{c}27.345^{* * *} \\
(4.434)\end{array}$ & $\begin{array}{c}24.300 * * * \\
(5.325)\end{array}$ \\
\hline Econ_Glob & & $\begin{array}{c}0.075^{* * *} \\
(0.022)\end{array}$ & $\begin{array}{c}0.074^{* * *} \\
(0.019)\end{array}$ & $\begin{array}{c}0.079 * * * \\
(0.016)\end{array}$ & $\begin{array}{c}0.082^{* * *} \\
(0.019)\end{array}$ & $\begin{array}{c}0.061^{* * *} \\
(0.019)\end{array}$ & $\begin{array}{c}0.069 * * * \\
(0.021)\end{array}$ \\
\hline Unemp & & & & $\begin{array}{c}0.067^{* *} \\
(0.025)\end{array}$ & $\begin{array}{c}0.072 * * * \\
(0.022)\end{array}$ & $\begin{array}{c}0.091^{* * *} \\
(0.021)\end{array}$ & $\begin{array}{c}0.104 * * * \\
(0.022)\end{array}$ \\
\hline Inflation & & & & & $\begin{array}{c}0.026 \\
(0.031)\end{array}$ & $\begin{array}{c}0.018 \\
(0.027)\end{array}$ & $\begin{array}{c}0.004 \\
(0.025)\end{array}$ \\
\hline $\log (G D P)$ & & & & & & $\begin{array}{c}3.751^{* * *} \\
(1.243)\end{array}$ & $\begin{array}{c}-42.059^{* * *} \\
(13.373)\end{array}$ \\
\hline $\log (G D P)^{\wedge} 2$ & & & & & & & $\begin{array}{c}5.157^{* * *} \\
(1.507)\end{array}$ \\
\hline Constant & $\begin{array}{c}21.150^{* * *} \\
(0.139)\end{array}$ & $\begin{array}{c}19.616^{* * *} \\
(0.405)\end{array}$ & $\begin{array}{c}33.624^{* * *} \\
(2.943)\end{array}$ & $\begin{array}{c}34.490^{* * *} \\
(3.012)\end{array}$ & $\begin{array}{c}34.082^{* * *} \\
(3.399)\end{array}$ & $\begin{array}{c}20.348^{* * *} \\
(5.900)\end{array}$ & $\begin{array}{c}120.694^{* * *} \\
(27.049)\end{array}$ \\
\hline R-squared & 0.381 & 0.455 & 0.493 & 0.509 & 0.511 & 0.523 & 0.538 \\
\hline No. of obs. & 532 & 532 & 532 & 532 & 532 & 532 & 532 \\
\hline No. of countries & 19 & 19 & 19 & 19 & 19 & 19 & 19 \\
\hline
\end{tabular}

Notes: ${ }^{*}$ significant at the 0.10 level, ${ }^{* *}$ significant at the 0.05 level, $* * *$ significant at the 0.01 level. Robust standard errors are presented in parentheses.

\subsection{Results of System-GMM Estimation}

Table 4 outlines the main results from the two-step system GMM estimation. The empirical findings show that the coefficients are very near to the full stability across models and have similarities to the results from the fixed-effects method. Hansen $J$-test indicates that there is no evidence of over-identifying restrictions. Although the AR(1) test results, which show the presence of first-order autocorrelation, do not find in Table 4, the $p$-values have a statistically significant pattern. However, this does not mean that the estimates are inconsistent. On the contrary, the inconsistency of estimates particularly relies upon the AR(2) test of second-order autocorrelation (Arellano and Bond, 1991). In other words, if the $p$-value of $A R(2)$ is significant, the inconsistency of estimates will be presented. In that vein, the $A R(2)$ test results in Table 4 indicate the absence of second-order autocorrelation. The major reason to take one-year lag of each variable depends on two factors. First, the time dimension is not too long to check the upper bounds of persistence in dependent variable. Second, since the number of instruments can exceed the number of countries, which is very problematic for providing consistent results, taking the number of lags is restricted in the models.

Contrary to the method of general-to-specific (Klomp and De Haan, 2012; Djalilov and Piesse, 2019), the system GMM models follow the specific-to-general procedure through adding control variables in different steps in terms of economic classifications of the variables. Initially, Model (1) estimates the partial correlation between income inequality and human capital without including the control variables for that relation among two variables. Then, Model (2) includes the economic globalization variable to control for the validity of Hypothesis 2 in the presence of removing the endogeneity problem from the regressions. The empirical estimates in Model (3) also add the square term of the human capital index to analyze the validity of the human capital Kuznets curve hypothesis of income inequality. The following models from (4) to (10) also considers the effects of control variables such as unemployment rate, inflation ratio, GDP per capita, and population, where their coefficients have the expected signs that was obtained in fixed-effects panel data method.

In particular, the results for the control variables indicate that unemployment and population have positive signs, while the sign is negative for the square term of GDP per capita though its coefficient is statistically insignificant. This implies that the bargaining position of workers are still effective on the level of income inequality. The results also show that inflation is only effective on income inequality in Model (9) and its coefficient is positive. This implies that the increase in the inflation ratio still maintains its negative impact on the purchasing power of households and thus reduces the level of income inequality. As for the other major variable, namely the human development index, to control the effects of proxy for education, life expectancy and per capita income on the level of income inequality, it does partially appear to have a statistically significant effect on GINI coefficient in Table 4. In other words, contrary to the results obtained 
in Table 2, the effects of human development index on the level of income inequality are only significant in the initial periods, representing in Models (8)-(10).

Finally, the variables of the GINI coefficient and $15-65$ years of population ratio is treated as endogenous, while the other variables are weakly-exogenous (pre-determined). Following the arguments provided by Roodman (2009), the system GMM assumes that the lags of instrumented variables are supposed to be the only available instruments. Therefore, the number of instruments is reduced by providing orthogonality conditions along with the use of a collapse option. Also, to follow the rule of thumb for the case of a number of instruments should be higher than the number of groups, the lags of instruments are selected based on this procedure.

Table 4. Results of Two-Step System GMM Estimation

\begin{tabular}{|c|c|c|c|c|c|c|c|c|c|c|}
\hline & (1) & (2) & (3) & (4) & (5) & (6) & (7) & (8) & (9) & (10) \\
\hline $\mathrm{GINI}_{\mathrm{t}-1}$ & $\begin{array}{c}1.001^{* * *} \\
(0.006)\end{array}$ & $\begin{array}{c}1.012^{* * *} \\
(0.006)\end{array}$ & $\begin{array}{c}0.736 * * * \\
(0.043)\end{array}$ & $\begin{array}{c}0.699 * * * \\
(0.047)\end{array}$ & $\begin{array}{c}0.618^{* * *} \\
(0.079)\end{array}$ & $\begin{array}{c}0.463^{* * *} \\
(0.155)\end{array}$ & $\begin{array}{c}1.053^{* * *} \\
(0.099)\end{array}$ & $\begin{array}{c}1.027^{* * *} \\
(0.010)\end{array}$ & $\begin{array}{c}0.790^{* * *} \\
(0.111)\end{array}$ & $\begin{array}{c}0.758^{* * *} \\
(0.130)\end{array}$ \\
\hline HumCap $_{\mathrm{t}-1}$ & $\begin{array}{c}0.510^{* * *} \\
(0.174)\end{array}$ & $\begin{array}{c}0.558^{* *} \\
(0.271)\end{array}$ & $\begin{array}{c}-159.044^{* * *} \\
(21.548)\end{array}$ & $\begin{array}{c}-179.367^{* * *} \\
(34.936)\end{array}$ & $\begin{array}{c}-230.579 * * * \\
(66.569)\end{array}$ & $\begin{array}{c}-239.335^{* * *} \\
(66.969)\end{array}$ & $\begin{array}{l}-19.926 \\
(48.134)\end{array}$ & & & \\
\hline HumCap^ $2_{\mathrm{t}-1}$ & & & $\begin{array}{c}23.873 * * * \\
(3.120)\end{array}$ & $\begin{array}{c}26.911 * * * \\
(5.256)\end{array}$ & $\begin{array}{c}34.459 * * * \\
(9.848)\end{array}$ & $\begin{array}{c}36.025^{* * *} \\
(9.936)\end{array}$ & $\begin{array}{c}2.829 \\
(6.964)\end{array}$ & & & \\
\hline Econ_Glob ${ }_{t-1}$ & & $\begin{array}{l}-0.015 \\
(0.014)\end{array}$ & $\begin{array}{c}0.083 * * * \\
(0.022)\end{array}$ & $\begin{array}{c}0.093 * * * \\
(0.024)\end{array}$ & $\begin{array}{c}0.118^{* *} \\
(0.055)\end{array}$ & $\begin{array}{l}0.131^{* *} \\
(0.056)\end{array}$ & $\begin{array}{c}0.007 \\
(0.050)\end{array}$ & $\begin{array}{l}-0.024 \\
(0.015)\end{array}$ & $\begin{array}{c}0.069 * * \\
(0.034)\end{array}$ & $\begin{array}{c}0.067^{* *} \\
(0.031)\end{array}$ \\
\hline Unemp $_{\mathrm{t}-1}$ & & & & $\begin{array}{c}0.015 \\
(0.022)\end{array}$ & $\begin{array}{c}0.010 \\
(0.025)\end{array}$ & $\begin{array}{c}-0.022 \\
(0.037)\end{array}$ & $\begin{array}{c}0.064^{* *} \\
(0.030)\end{array}$ & $\begin{array}{c}0.035 * * * \\
(0.013)\end{array}$ & $\begin{array}{c}0.105 * * * \\
(0.030)\end{array}$ & $\begin{array}{c}0.096 * * * \\
(0.033)\end{array}$ \\
\hline Inflation $_{\mathrm{t}-1}$ & & & & & $\begin{array}{l}-0.030 \\
(0.028)\end{array}$ & $\begin{array}{c}0.008 \\
(0.043)\end{array}$ & $\begin{array}{l}-0.009 \\
(0.038)\end{array}$ & $\begin{array}{l}-0.007 \\
(0.010)\end{array}$ & $\begin{array}{c}0.041^{* *} \\
(0.019)\end{array}$ & $\begin{array}{c}0.019 \\
(0.018)\end{array}$ \\
\hline $\log (G D P)_{t-1}$ & & & & & & $\begin{array}{l}-8.562 \\
(7.400)\end{array}$ & $\begin{array}{c}150.158 \\
(123.564)\end{array}$ & & & \\
\hline $\log (G D P)^{\wedge} 2_{t-1}$ & & & & & & & $\begin{array}{l}-15.911 \\
(12.872)\end{array}$ & & & \\
\hline $\mathrm{HDI}_{\mathrm{t}-1}$ & & & & & & & & $\begin{array}{c}3.828^{* *} \\
(1.843)\end{array}$ & $\begin{array}{c}10.615^{*} \\
(6.023)\end{array}$ & $\begin{array}{c}356.129 \\
(253.660)\end{array}$ \\
\hline$\left.\mathrm{HDI}\right|^{\wedge} \mathrm{Z}_{\mathrm{t}-1}$ & & & & & & & & & & $\begin{array}{l}-191.925 \\
(140.008)\end{array}$ \\
\hline Population $_{\mathrm{t}-1}$ & & & & & & & & & $\begin{array}{l}0.160^{* *} \\
(0.074)\end{array}$ & $\begin{array}{r}0.203 * * \\
(0.082)\end{array}$ \\
\hline Constant & $\begin{array}{c}-1.654^{* *} \\
(0.666)\end{array}$ & $\begin{array}{l}-1.013^{*} \\
(0.585)\end{array}$ & $\begin{array}{c}264.700^{* * *} \\
(36.438)\end{array}$ & $\begin{array}{c}298.707^{* * *} \\
(57.853)\end{array}$ & $\begin{array}{c}385.658^{* * *} \\
(110.343)\end{array}$ & $\begin{array}{c}440.974 * * * \\
(120.153)\end{array}$ & $\begin{array}{l}-321.596 \\
(245.325)\end{array}$ & $\begin{array}{c}-2.531^{* * *} \\
(0.780)\end{array}$ & $\begin{array}{c}-20.210^{* *} \\
(9.869)\end{array}$ & $\begin{array}{l}-177.251 \\
(115.876)\end{array}$ \\
\hline Wald test (prob.) & 0.000 & 0.000 & 0.000 & 0.000 & 0.00 & 0.000 & 0.000 & 0.000 & 0.000 & 0.000 \\
\hline Hansen J-test & 0.48 & 0.44 & 0.61 & 0.57 & 0.62 & 0.66 & 0.40 & 0.48 & 0.42 & 0.45 \\
\hline$A R(2)$ test & 0.28 & 0.31 & 0.12 & 0.11 & 0.09 & 0.12 & 0.78 & 0.40 & 0.61 & 0.81 \\
\hline No. of inst. & 17 & 17 & 17 & 17 & 17 & 17 & 17 & 17 & 17 & 17 \\
\hline No. of obs. & 304 & 304 & 304 & 304 & 304 & 304 & 304 & 304 & 304 & 304 \\
\hline No. of countries & 19 & 19 & 19 & 19 & 19 & 19 & 19 & 19 & 19 & 19 \\
\hline
\end{tabular}

Notes: * significant at the 0.10 level, $* *$ significant at the 0.05 level, ${ }^{* * *}$ significant at the 0.01 level. All models use the system GMM produced by Arellano and Bover (1995) and Blundell and Bond (1998) and extended by Roodman (2006) for the two-step covariance matrix. The regression results provide Hansen J-test statistics to specify whether the overidentifying restrictions are significant or not. The collapsing method is used in each model to get rid of too-many-instruments problem and hence to provide orthogonality conditions. The joint null hypothesis implies that the instruments are valid, which means that they are uncorrelated with the error term and that the excluded instruments are correctly ignored from the estimated equation. The results of $\operatorname{AR}(2)$ are also provided to check for autocorrelation in case of proper maximum lag distance.

\section{Concluding Remarks}

Over the last three decades, the investigation of human capital accumulation process coupled with increasing level of education attainment and spurring progress in technology has received renewed interest from different disciplines to seek an answer whether it is highly correlated with the level of income inequality. In particular, the analysis of the effects of skills on economic growth, income distribution, efficiency, and social stratification has become crucial determinants in the research field related to educational attainment. However, the examination of the impact of human capital accumulation along with the increasing degree of economic globalization on income inequality in the long run has barely aroused interest in the literature.

This study inquires the effects of human capital accumulation on the level of income inequality in 19 advanced economies over the 1990-2017 period, along with integrating the theoretical ingredients of how can be the increasing degree of economic globalization affects the relationship between the two. For that reason, the study is divided into two parts in terms of the theoretical reason that economic globalization can 
have a direct effect on income inequality and can have an indirect effect on distribution through the channel of human capital accumulation. There is no evidence to terminate the discussion that the human capital has a positive impact on distributing the total income, especially in the presence of complex effects of economic globalization on socio-economic dynamics in different economies. Therefore, it is essential to reveal the major determinants of the link between human capital accumulation and income inequality in the sample of selected 19 advanced economies considering the ongoing changes in globalized economic units.

The study contributes to the existing literature in several aspects. Firstly, it enhances the studies in a number of ways by (i) considering the early and later stages of human capital; (ii) assessing the effects of economic globalization; (iii) providing crucial details on stylized facts; and (iv) applying two-step system GMM to consider the endogeneity problem and the dynamic nature of GINI coefficient, human capital, and the rest of the other variables. Secondly, this study provides several empirical outputs based on education-inequality nexus in advanced economies where the level of educational attainment and the level of efficiency in production are relatively high.

The empirical findings indicate that human capital accumulation in 19 advanced economies is positively correlated with the level of income inequality for the period 1990-2017. Also, the distinction among the periods by assessing the early and later stages of human capital on income inequality provides particular results to understand the long run process between the two indicators. While the initial stages of accumulating a higher degree of human capital through increasing the average years of schooling and returns to education reduce the level of income inequality, the later stages show that this negative relationship turns into positive. In other words, the long run assessment of education-inequality provides a piece of information that the human capital accumulation increases the level of income inequality by widening the opportunities for more privileged people in advanced economies. Also, contrary to the mainstream arguments, the economic globalization appears to be positively correlated with income inequality, meaning that globalized economic relations widen the scale of inequality. Moreover, both fixed-effects and system GMM procedures indicate that the above-mentioned empirical findings are substantially validated in most of the regressions in control of several indicators, including both bargaining power measures for labor and macroeconomic variables.

Overall, the empirical outputs ascertain different policy conclusions. First, the results show that the human capital accumulation is positively correlated with the level of income inequality in the long run. Second, contrary to the orthodox views, the globalization of the overall economy does not provide advantageous outputs in terms of reducing income inequality. This suggests that policymakers should be in caution in consideration of making trade and finance more open to foreign countries. If this urgently becomes the main policy tool of any country from the developed region, the executives should need to consider the specifications of their economic background and current economic indicators. Moreover, the bargaining position of workers has a significant impact on income distribution by widening the inequality where it is proxied by the unemployment rate and $15-65$ years of population ratio.

\section{Disclosure Statements}

1. The author of this article confirms that her work complies with the principles of research and publication ethics.

2. No potential conflict of interest was reported by the author.

3. This article was screened for potential plagiarism using a plagiarism screening program. 


\section{End Notes}

1. The sample countries can be ranged as follows: Australia, Austria, Belgium, Canada, Denmark, Finland, France, Germany, Italy, Japan, Netherlands, Norway, Singapore, South Korea, Spain, Sweden, Switzerland, the United Kingdom, and the United States.

2. The methodological similarity can also be found in the study proposed by Hovhannisyan et al. (2019).

3. The abbreviations in Table 1 can be extended as follows: (i) GINI: Gini_Net data of disposable income inequality; (ii) HumCap: Human capital index; (iii) EconGlob: Economic globalization index; (iv) Unemp: Unemployment rate, total (\% of total labor force, modeled ILO estimate); (v) GDP: Logarithm of GDP per capita (constant 2010 US\$); (vi) Inflation: Inflation, consumer prices (annual \%); (vii) Population: Population ages 15-65 (\% of total population); (vii) HDI: Human development index; (ix) Education: Education index.

\section{References}

Acemoglu, D., \& Autor, D. (2010). Skills, tasks and technologies: implications for employment and earnings. NBER Working Paper No. 16082, National Bureau of Economic Research.

Andersen, T. M. (2019). Social background, education, and inequality. Economic Inquiry, 57(3), 1441-1459.

Andersen, T. G., \& Sørensen, B. E. (1996). GMM estimation of a stochastic volatility model: A Monte Carlo study. Journal of Business and Economic Statistics, 14(3), 328-352.

Arellano, M., \& Bond, S. R. (1991). Some tests of specification for panel data: Monte Carlo evidence and an application to employment equations. Review of Economic Studies, 58(2), 277-297.

Arellano, M., \& Bover, O. (1995). Another look at the instrumental variable estimation of error-components models. Journal of Econometrics, 68(1), 29-51.

Atkinson, A. B., Piketty, T., \& Saez, E. (2011). Top incomes in the long run of history. Journal of Economic Literature, 49(1), 3-71.

Autor, D. (2014). Skills, education, and the rise of earnings inequality among the "other 99 percent". Science, 344(6186), 843-851.

Barro, R. J., \& Lee, J. W. (2013). A new data set of educational attainment in the world, 1950-2010. Journal of Development Economics, 104, 184-198.

Battistón, D., García-Domench, C., \& Gasparini, L. (2014). Could an increase in education raise income inequality? Evidence for Latin America. Latin American Journal of Economics, 51(1), 1-39.

Becker, G. S. (1962). Investment in human capital: A theoretical analysis. Journal of Political Economy, 70(5), 9-49.

Becker, G. S., \& Tomes, N. (1979). An equilibrium theory of the distribution of income and intergenerational mobility. Journal of Political Economy, 87(6), 1153-1189.

Blundell, R., \& Bond, S. (1998). Initial conditions and moment restrictions in dynamic panel data models. Journal of Econometrics, 87(1), 115-143.

Bol, T. \& van de Werfhorst, H. G. (2013). Educational systems and the trade-off between labor market allocation and equality of educational opportunity. Comparative Education Review, 57(2), 285-308.

Bourguignon, F., Ferreira, F. H. G., \& Lustig, N. (2005). The microeconomics of income distribution dynamics in East Asia and Latin America. Washington, D.C.: World Bank Publications.

Bowsher, C. G. (2002). On testing overidentifying restrictions in dynamic panel data models. Economics Letters, 77(2), 211-220.

Campos-Vazquez, R., Esquivel, G., \& Lustig, N. (2014). The rise and fall of income inequality in Mexico, 1989-2010. In Falling inequality in Latin America: policy changes and lessons, G. A. Cornia (ed.), New York: Oxford University Press.

Che, Y., Lu, Y., Tao, Z., \& Wang, P. (2013). The impact of income on democracy revisited. Journal of Comparative Economics, 41(1), 159-169.

Checchi, D. (2000). Does educational achievement help to explain income inequality? WIDER Working Paper No. 208/2000, United Nations University World Institute for Development Economics Research.

Checchi, D. (2001). Education, inequality and income inequality, DARP 52. Suntory and Toyota International Centres for Economics and Related Disciplines. London, UK: London School of Economics and Political Sciences. 
Checchi, D., \& van de Werfhorst, H. G. (2014). Educational policies and income inequality. IZA Discussion Paper No. 8222.

Dabla-Norris, E., Kochhar, K., Suphaphiphat, N., Ricka, F., \& Tsounta, E. (2015). Causes and consequences of income inequality: A global perspective. IMF Staff Discussion Notes 15/13, International Monetary Fund.

De Gregorio, J., \& Lee, J-W. (2002). Education and income inequality: New evidence from cross-country data. The Review of Income and Wealth, 48(3), 395-416.

Djalilov, K., \& Piesse, J. (2019). Bank regulation and efficiency: Evidence from transition countries. International Review of Economics and Finance, 64, 308-322.

Driscoll, C. J., \& Kraay, C. A. (1998). Consistent covariance matrix estimation with spatially dependent panel data. Review of Economics and Statistics, 80(4), 549-560.

Durlauf, S. N. (1996). A theory pf persistent income inequality. Journal of Economic Growth, 1(1), 75-93.

Ehrlich, I., \& Kim, J. (2007). The evolution of income and fertility inequalities over the course of economic development: A human capital perspective. Journal of Human Capital, 1(1), 137-174.

Feenstra, R. C., Inklaar, R., \& Timmer, M. P. (2015). The next generation of the Penn World Table. American Economic Review, 105(10), 3150-3182.

Földvári, P., \& van Leeuwen, B. (2011). Should less inequality in education lead to a more equal income distribution? Education Economics, 19(5), 537-554.

Galor, O. (2012). Inequality, human capital formation and the process of development. IZA Discussion Paper No. 6328.

Galor, O., \& Zeira, J. (1993). Income distribution and macroeconomics. The Review of Economic Studies, 60(1), 35-52.

Galor, O., \& Tsiddon, D. (1997). The distribution of human capital and economic growth. Journal of Economic Growth, 2(1), 93-124.

Galor, O., \& Moav, O. (2004). From physical to human capital accumulation: Inequality and the process of development. Review of Economic Studies, 71(4), 1001-1026.

Goldin, C., \& Katz, L. F. (2010). The race between education and technology. Cambridge: Belknap Press.

Gregg, P., Macmillan, L. \& Vittori, C. (2019). Intergenerational income mobility: Access to top jobs, the low-pay no-pay cycle and the role of education in a common framework. Journal of Population Economics, 32(2), 501-528.

Hansen, L. P. (1982). Large sample properties of generalized method of moments estimators. Econometrica, 50(4), 10291054.

Hanushek, E. A., \& Wossmann, L. (2011). The economics of international differences in educational achievement. In Handbooks of the Economics of Education, E. A. Hanushek S. Machin, and L. Wossmann (eds.), 89-200, The Netherlands: North Holland/Elsevier.

Heid, B., Langer, J., \& Larch, M. (2012). Income and democracy: Evidence from system GMM estimates. Economics Letters, 116(2), 166-169.

Hovhannisyan, A., Castillo-Ponce, R., \& Valdez, R. I. (2019). The determinants of income inequality: The role of education. Scientific Annals of Economics and Business, 66(4), 451-464.

Im, K. S., Pesaran, M. H., \& Shin, Y. (2003). Testing for unit roots in heterogeneous panels. Journal of Economics, 115(1), 53-74.

Jaumotte, F., Lall, S., \& Papageorgiou, C. (2013). Rising income inequality: Technology, or trade and financial globalization. IMF Economic Review, 61, 217-309.

Kaldor, N. (1957). A model of economic growth. The Economic Journal, 67(268), 591-624.

Katz, L. F., \& Murphy, K. M. (1992). Changes in relative wages, 1963-1987: Supply and demand factors. Quarterly Journal of Economics, 107(1), 35-78.

Klomp, J., \& De Haan, J. (2012). Banking risk and regulation: Does one size fit all? Journal of Banking and Finance, 36(12), 3197-3212.

Knight, J. B., \& Sabot, R. H. (1983). Educational expansion and the Kuznets effect. American Economic Review, 73(5), 1132-1136.

Kuznets, S. (1955). Economic growth and income inequality. American Economic Review, 45(1), 1-28.

Lustig, N., Lopez-Calva, L., Ortiz-Juarez, E., \& Monga, C. (2016). Deconstructing the decline in inequality in Latin America. In Inequality and growth: patterns and policy, K. Basu and J. Stiglitz (eds.), New York: Palgrave Macmillan. 
Milanovic, B. (2018). Global inequality: a new approach for the age of globalization. Cambridge, MA: Belknap Press, an Imprint of Harvard University Press.

Mincer, J. (1958). Investment in human capital and personal income distribution. Journal of Political Economy, 66(4), 281-302.

Mitchell, M. F. (2005). Specialization and the skill premium in the 20th century. International Economic Review, 46(3), 933-955.

Montenegro, C. E., \& Patrinos, H. A. (2014). Comparable estimates of returns to schooling around the world. Policy Research Working Paper WPS 7020, Washington, D.C.: World Bank Group.

Organisation for Economic Co-operation and Development (OECD). (2008). Growing unequal? Income distribution and poverty in OECD countries. Paris: OECD Publishing.

Organisation for Economic Co-operation and Development (OECD). (2014). Education at a glance 2014. Paris: OECD Publishing.

Park, K. H. (1996). Educational expansion and educational inequality on income distribution. Economics of Education Review, 15(1), 51-58.

Peracchi, F. (2006). Educational wage premia and the distribution of earnings: An international perspective. In Handbook of the economics of education-vol.1, E. Hanushek and F. Welch (eds.), 189-254, Amsterdam: Elsevier North Holland.

Pfeffer, F. T. (2008). Persistent inequality in educational attainment and its institutional context. European Sociological Review, 24(5), 543-565.

Piketty, T. (2014). Capital in the twenty-first century. Cambridge, MA: Harvard University Press.

Psacharopoulos, G. (1994). Returns to investment in education: A global update. World Development, 22(9), 1325-1343.

Psacharopoulos, G., \& Patrinos, H. (2004). Returns to investment in education: A further update. Education Economics, 12(2), 111-134.

Ram, R. (1984). Population increase, economic growth, educational inequality, and income distribution: Some recent evidence. Journal of Development Economics, 14(3), 419-428.

Ram, R. (1990). Educational expansion and schooling inequality: International evidence and some implications. The Review of Economics and Statistics, 72(2), 266-274.

Rodríguez-Pose, A., \& Tselios, V. (2009). Education and income inequality in the regions of the European Union. Journal of Regional Science, 49(3), 411-437.

Roodman, D. (2006). How to do xtabond2: An introduction to "difference" and "system" GMM in Stata. Center for Global Development, Working Paper No. 103, December.

Roodman, D. (2009). A note on the theme of too many instruments. Oxford Bulletin of Economics and Statistics, 71(1), 135-158.

Rumberger, R. W. (2010). Education and the reproduction of economic inequality in the United States: An empirical investigation. Economics of Education Review, 29(2), 246-254.

Saint-Paul, G., \& Verdier, T. (1993). Education, democracy and growth. Journal of Development Economics, 42(2), 399407.

Solt, F. (2019). Measuring income inequality across countries and over time: The standardized world income inequality database. SWIID Version 8.2, November.

Spence, M. (1973). Job market signaling. The Quarterly Journal of Economics, 87(3), 355-374.

Thomas, V., Wang, Y., \& Fan, X. (2002). A new dataset on inequality in education: Gini and Theil indices of schooling for 140 countries. Washington, DC: World Bank.

Viaene, J-M., \& Zilcha, I. (2003). Human capital formation, income inequality, and growth. In Inequality and growth: theory and policy implications, Theo S. Eicher and Stephen J. Turnovsky (eds.), Cambridge, MA: The MIT Press.

Williamson, J. G. (1991). Inequality, poverty, and history: The Kuznets memorial. Oxford: Blackwell Publishing.

Wolf, A. (2004). Education and economic performance: Simplistic theories and their policy consequences. Oxford Review of Economic Policy, 20(2), 315-333.

Wossmann, L. (2005). The effect heterogeneity of central examinations: Evidence from TIMSS, TIMSS-Repeat and PISA. Education Economics, 13(2), 143-169. 
This Page Intentionally Left Blank 